\title{
IMPLEMENTATION OF CORPORATE SOCIAL RESPONSIBILITY PROGRAM IN GRESIK PETROCHEMICAL
}

\author{
Riswanto Iwan*, Subiyanto Agus, Rianto Budi \\ University of Hang Tuah, Surabaya, Indonesia \\ ${ }^{\star}$ E-mail: iwan.riswanto.0020@gmail.com
}

\begin{abstract}
Objective of the study is to describe and analyze the process of implementing the Corporate Social Responsibility of Gresik Petrochemical and describe and analyze supporters and inhibitors in the implementation of Corporate Social Responsibility Program. Gresik Petrochemical. Data analysis method uses interactive model analysis with three procedures, namely data reduction, data presentation and conclusion / verification. The research findings generally show that the implementation of Corporate Social Responsibility programs has been carried out in an integrated manner that includes standard instruments and policy targets, resources, characteristics of implementing organizations, communication between organizations and implementing activities, dispositions or attitudes of executors, social, economic and political conditions.
\end{abstract}

\section{KEY WORDS}

Implementation, public policy, corporate social responsibility, public service.

Corporate Social Responsibility is an important activity for the company. Corporate Social Responsibility is an action or concept carried out by the company (according to the ability of the company) as a form of their responsibility towards the social / environment around where the company is located. In Indonesia, CSR is regulated by the Law of the Republic of Indonesia Number 40 of 2007 concerning Article 74 Limited Liability Companies Social and Environmental Responsibility. The content of the law is to require companies in the form of limited liability companies (PT) to carry out corporate social responsibility activities.

Every company does not only aim to maximize profits. But in carrying out the survival of the company a social responsibility and an increase in social welfare are needed so that the company is not only a part of being responsible to its owner (Soraya, 2011). Society and the natural environment are the main sources of the most important production factors for the activities and existence of the company. Without society and the natural environment, the company will never exist and be able to develop. Companies can grow and develop because of the factors of production. That is why the Company has social responsibility or Corporate Social Responsibility for the existence of society and natural environment (Marlia and Hidayat, 2008).

The basic principle in the Corporate Social Responsibility strategy of Gresik Petrochemical is sustainable development which adopts the triple bottom line concept which is elaborated through the application of 6 pillars of sustainable development. If combined with 6 pillars of Corporate Social Responsibility according to Petro Chemistry, the mindset is expected by the company to always strive to concentrate on creating sustainable products and sustainable construction, energy and climate, resource conservation and social commitment. All Corporate Social Responsibility programs use the partnership method.

The Corporate Social Responsibility program is useful in the long time where programs have a positive impact on the progress of society and the relationship between the community and the company for a long period of time, even if it is possible to create a psychological relationship for life. This program is managed by involving the community and promoting the independence of the community to take care of the sustainability of the program. The role taken by the company, in this case the division in charge of the Corporate Social Responsibility program, should act as a "companion" of the community, which bridges 
communication between the company and the community and vice versa (Ruhliana, 2012). The practice of Corporate Social Responsibility is indeed inseparable from the term stakeholders, because the slices are large between influencing and being influenced related to the fulfillment of each other's needs. In simple terms the definition of stakeholders is groups that influence and / or are influenced by the organization as a result of activities (Rahmatullah and Kurniati, 2011).

Healthy village program is a very unique program from the program. ....views the existence of the company which has a negative impact on local residents, especially those that are closest to the plant's operational location. Until now the impact of the existence of the Gresik Petrochemical is still felt by local residents, especially in terms of air pollution and health. A series of negative effects produced by the company converged on the fact of the importance of CSR programs in the health sector. To reduce citizen protests and minimize the negative impacts generated by surrounding communities, programs that have been implemented since 2010 will continue in line with the Sustainability concept that CSR must be adhered.

The descriptions above can be concluded that implementation is the application of something that has been agreed upon in advance. So that the implementation will lead to the activity or mechanism of a system. From the word mechanism, it can be seen that implementation is not just an activity, but an activity that is planned and carried out seriously based on guidelines from certain norms to achieve the objectives of the activity.

\section{THEORETICAL FRAMEWORK AND HYPOTHESIS}

Conceptual Definition of Public Policy Implementation. Policy is seen as a process, which includes formulation, implementation and evaluation. A policy is formulated or formulated with a view to achieving certain goals. Islamy (2000) argues that: "there are state policies that are self-executing, but the most are non-self-executing, meaning that state policies need to be realized and implemented by various parties so that the effect appears.

Anderson (1979) suggested that policy implementation can be seen in four aspects, there for "Who is involved in policy implementation, the nature of the administrative process, compliance with policy, and the effect of implementation on the impact of policy content". (Who implements policies, the nature of administrative processes, compliance with policies, and the effects of policy implementation and impact).

Public policy actually has become a social reality since humans realize that they have the same life goals in addition to the variety of interests that exist. The basic definition of public policy is the realization of the desire of social scholars to solve social problems in the field (close the gap between knowledge and policy) (Parsons, 2005: 21). Therefore public policy is seen as a guideline or guide chosen by decision makers to control certain aspects of social problems (Finsterbuch and Motz, 1990).

Van Meter and Van Horn (Winarno, 2008) define the implementation of public policy as actions in previous decisions. These actions include attempts to convert decisions into operational actions within a certain period of time or in order to continue efforts to achieve large and small changes determined by policy decisions carried out by public organizations directed to achieve set goals

According to Van Meter and Van Horn (Subarsono, 2005), there are six variables that affect implementation performance, that is:

1. Policy standards and targets. Policy standards and targets must be clear and measurable so that they can be realized;

2. Resources. Policy implementation needs to support resources both human resources and non-human resources;

3. Relationships between Organizations. In many programs, the implementation of a program needs support and coordination with other institutions;

4. Characteristics of implementing agents. What is meant by the characteristics of implementing agents includes the structure of the bureaucracy, norms, and patterns of 
relations that occur in the bureaucracy, all of which will affect the implementation of a program;

5. Social, political and economic conditions. This variable includes environmental economic resources that can support the success of policy implementation;

6. Disposition of the implementor. The implementor's disposition includes three important things, namely: the implementor's response to the policy, which will influence the way to implement the policy, and the intensity of the disposition of the implementor, namely the value preferences possessed by the implementor.

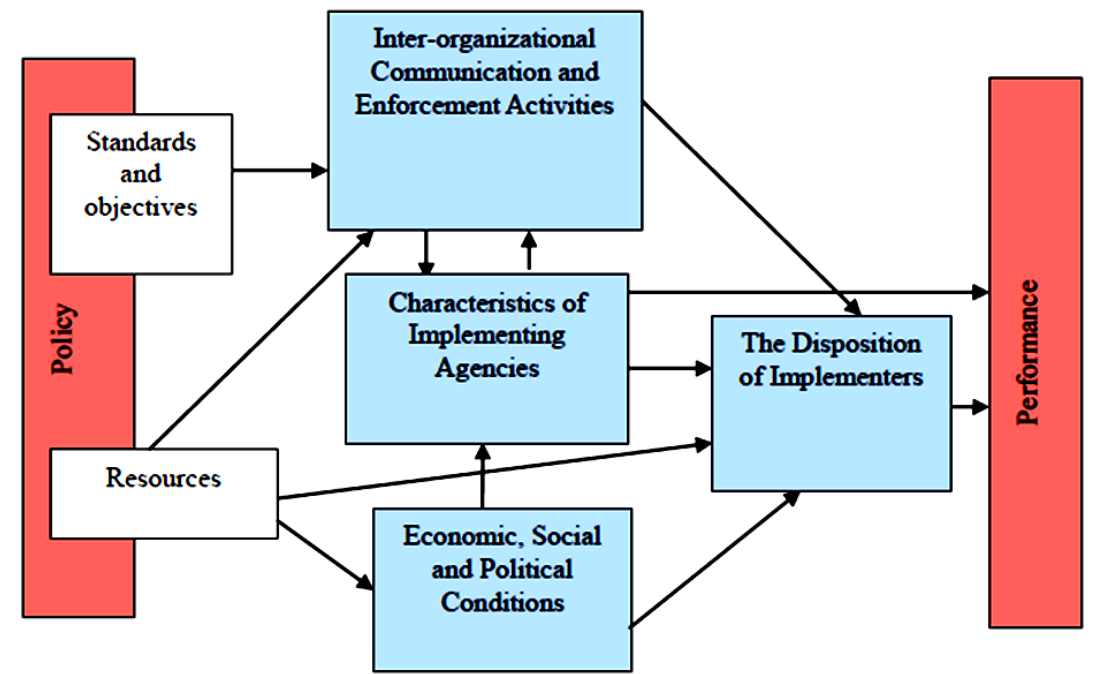

Figure 1 - Policy Implementation According to Van Meter and Van Horn (Source: Van Meter dan Van Horn, Subarsono, 2005)

Corporate Social Responsibility. CSR is the company's commitment in acting ethically and contributing to economic and social improvement to all its stakeholders and taking good care of the environment around the company in order to achieve sustainable development goals. Johnson (2006) in Hadi (2011) defines Corporate Social Responsibility is about how companies manage business processes and overall positive impact on society. This definition basically departs from the philosophy of how to manage a company, both partially and as a whole has a positive impact on the company and the environment. Therefore, companies must be able to manage their operations by producing products that are positively oriented towards society and the environment

David Crowther (2008) states that outlining the principles of corporate social responsibility into three, namely: First, Sustainability related to how companies in activities (actions) still take into account the sustainability of resources in the future. Secondly, Accountability is an effort of an open company and is responsible for activities that have been carried out. Accountability can be used as a medium for companies to build an image (image) and network of stakeholders. Third, Transparency is an important principle for external parties whose role is to reduce information asymmetry, misunderstanding, especially information and accountability for various environmental impacts.

Chakrabhoty (2010) concluded that Corporate Social Responsibility is about how companies manage business processes to get a positive overall impact on society. Thus the company considers the interests of the community by taking responsibility for the impact of their activities on customers, suppliers, employees, community and other stakeholders. In line with this understanding Tanaya (2004) states that the essence of Corporate Social Responsibility is a manifestation of giving back to the community or the surrounding community, which can be done to produce a business based on sincere intention to make the most positive contribution to the surrounding community (Stakeholders).

Framework of Thinking and Hypothesis. Attention to the practice of social responsibility is important because it has coherence with sustainable development and teaches to behave 
in a balanced, harmonious and harmonious manner, so that exploitation that leads to threats of environmental damage can be avoided. David Crowther (2008) outlines the principles of corporate social responsibility into three, namely: First, Sustainability related to how companies conduct activities (action) still takes into account the sustainability of resources in the future. Secondly, Accountability is an effort of an open company and is responsible for the activities that have been carried out. Accountability can be used as a medium for companies to build an image (image) and network of stakeholders. Third, Transparency is an important principle for external parties whose role is to reduce information asymmetry, misunderstanding, especially information and accountability for various environmental impacts.

The company is not only responsible for the shareholders, but is shifting into a wider range, namely reaching the social realm, hereinafter referred to as CSR. Such a phenomenon occurs because of demands from the community due to negative externalities that arise as well as social inequalities that occur. Companies should pay attention to stakeholders and the social and community environment because they are parties that influence and are influenced both directly and indirectly on the activities and policies taken and carried out by the company. If the company does not pay attention to the stakeholders and the social and community environment, it is not impossible to reap protests and make the corporate image become negative.

Based on these theoretical assumptions, Gresik Petrochemical cannot escape its surrounding social environment. The negative image will be formed if Gresik Petrochemical does not pay attention to its stakeholders. After carrying out all the Public Relations management processes for CSR program activities, feedback will occur from the public concerned with the CSR program implemented. The feedback given by the public will shape the corporate image (corporate image) of Gresik Petrochemical. Positive images of the community can be felt, and help in sustainable development. Finally, Corporate Social Responsibility activities at Gresik Petrochemical can be managed professionally and transparently so that CSR as one of the implementation of good corporate governance can be realized soon.

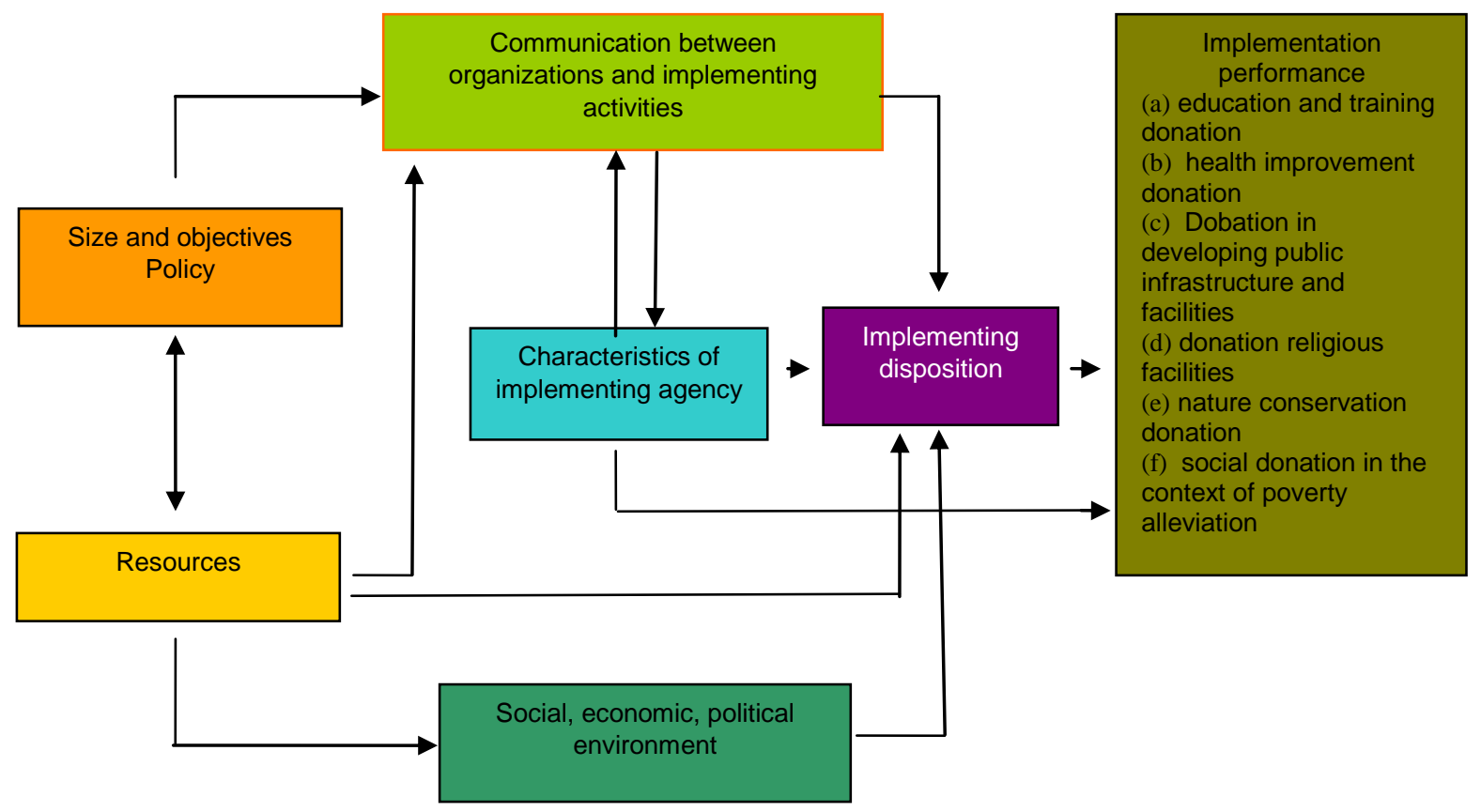

Figure 2 - Framework of Thinking

Based on the combination and elaboration of variables that influence implementation performance, namely policy standards and targets, resources, inter-organizational communication and strengthening activities, characteristics of implementing agencies, social, 
economic and political conditions, implementers' dispositions and implementation performance are expected to increase implementation of Corporate Social Responsibility programs.

Hypotheses. Based on the framework, the hypothesis is as follows:

The implementation of Corporate Social Responsibility will be useful if the mechanism is integrated, which includes policy standards and targets, resources, inter-organizational communication and strengthening activities, characteristics of implementing agencies, social, economic and political conditions, implementation of implementers and implementation performance harmonized with objectives and company mission in implementing Corporate Governance.

Subject of the Study. The subject of this study is the location included in the ring I company for the implementation of CSR.

Respondents are the Human Resources Section of Gresik Petrochemical, part of the implementation of Gresik Petrochemical CSR, Community Leader, Village Head, Chairperson of RW / RT. Data collection techniques used in this study were through interviews, observation, and documentation.

The object of research is a Corporate Social Responsibility program which covers aspects of Standard and policy objectives, Resources, Inter-organizational Communication and strengthening activities, Characteristics of implementing agents, Social, economic and political conditions, Disposition of implementers and Performance of implementation. These objects become research variables and analyzed using interactive model analysis with three procedures, namely data reduction, data presentation and conclusion / verification.

\section{METHODS OF RESEARCH}

This study applies a qualitative method that is descriptive qualitative by explaining that a policy is said to be successful if the policy implemented has the desired impact. In this study qualitative methods were used to explain the Implementation of the Corporate Social Responsibility Program. This method is used to explain the purpose and objectives of the study where some of the questions that arise as well as the data obtained, such as the policy implementation process, factors that influence the implementation of the Corporate Social Responsibility Program Gresik Petrochemical.

The unit of analysis is the Standard and target of policies, Resources, Interorganizational Communication and strengthening activities, Characteristics of implementing agents, Social, economic and political conditions, Disposition of implementers and Implementation performance. Data analysis method uses data analysis that has been developed by Miles and Huberman (in Emzir, 2010), using ineractive model analysis with three procedures, namely data reduction by simplifying data from various sources and various methods to determine themes and organize data according to focus. research covering policy standards and objectives, resources, inter-organizational communication and strengthening activities, characteristics of implementing agents, social, economic and political conditions, implementor's disposition and implementation performance. Submission of data is done by using tables and images related to the Implementation of the Corporate Social Responsibility Program. Drawing conclusions / verification by means of any conclusions will always continue to be verified during the research that involves the interpretation of the researcher.

\section{RESULTS AND DISCUSSION}

The performance of policy implementation can be measured by its success from the size and realistic policy objectives with socio-culture at the level of policy implementers. Therefore it is necessary to carry out standardization and policy objectives. An understanding of the general intentions of a standard and policy objectives is important. Successful policy implementation may fail when the implementers are not fully aware of the standards and 
policy objectives. Policy standards and objectives have a close relationship with the disposition of implementers (implementors).

Based on the results of the study it was found that both the company and the community had synchronization between the answers of the company and the community. It meant that the company prepared a program and the community felt the benefits of the program implemented in the kelurahan so that it could be stated that the standard implementation of policy objectives.

The success of policy implementation depends on the ability to utilize available resources. The most important resource in determining the success of a policy implementation is human resources and financial resources. Every stage of implementation requires the existence of quality human resources in accordance with the work that is implied by politically determined policies and how incentives for their employees.

Based on the results of the study it was found that the ability of the implementing staff in the field that had been provided with the skills and experience possessed by CSR program activities could be carried out well and run smoothly in accordance with the opinion conveyed by the informant that the training program held by the company was very necessary to increase community skills.

The characteristics of implementing organizations that are of concern include formal organizations and informal organizations which will be involved in implementing the policy. This is important because the performance of policy implementation will be greatly influenced by the right characteristics and match with the implementing agents. This is related to the context of the policy that will be implemented in several policies that are demanded by implementing strict policies and discipline as well as being needed by democratic and persuasive implementing agents.

The results of the study showed that the officers had carried out their duties well because they had the characteristics of the implementing organization in the form of clear and easily understood SOPs so that each officer was able to understand what was the responsibility of his work.

Public policy can be implemented effectively. Required standards of goals must be understood by individuals (implementors). Who is responsible for achieving policy standards and objectives, therefore standards and objectives must be communicated to the implementers. Communication within the framework of delivering information to policy implementers about what is the standard and objectives must be consistent and uniform from various sources of information. If there is no clarity and consistency and uniformity towards a standard and policy objectives, then the standard and policy objectives are difficult to achieve.

The executor has carried out the task well because it has communication between related organizations and implementation activities. Officers have communicated well with fellow bureaus / departments and especially with recipients of CSR programs, while for the community it can also be felt the ease of receiving programs implemented in their area.

The attitude of acceptance or rejection of policy implementing agents greatly influences the success or failure of public policy implementation. This is because the policy implemented is not the result of the formulation of local residents who know the problems and problems that they feel. But public policy is usually top down which is very likely that decision makers do not know that they cannot even touch the needs, desires or problems that must be resolved.

The executor or officer has carried out the task well because he understands and knows the disposition or attitude of the implementers. Officers have worked professionally so that they can carry out their duties properly. Whereas for the community it can be felt with the benefit of the implementation of the program implemented in the region

The performance of policy implementation can be seen by emphasizing the extent to which the external environment contributes to the success of public policy. The social, economic and political environment that is not conducive can be a source of problems from the failure of policy implementation performance. Then it is necessary to implement policies that require external environmental conditions. Officers have carried out their duties well 
because the social, economic and political environment in the village of mud is quite safe and smooth. Executing tasks in the field can work professionally because the work environment is conducive, safe, clean and smooth

In general, Gresik Petrochemical divides the dimensions of CSR activities in two fields, namely social development consisting of community involvement and economic development, and evironment. Community involution is a CSR activity that aims to provide facilities and infrastructure and to conduct partnership and community development activities. Facilities and facilities provided include spiritual facilities, education, economics, sports and health. Whereas for partnership and community development activities consists of five fields, namely: (a) education and training assistance (b) health improvement assistance (c) assistance in developing public infrastructure and facilities (d) assistance for religious facilities (e) natural pelesterian assistance (f ) community social assistance in the context of poverty alleviation

Gresik Petrochemical, among others, HR from companies that carry out in the field from PT. Gresik Petrochemicals that have been trained and experienced in handling CSR activities, Executors in the field already have an SOP for the implementation of CSR activities so that all program implementation activities will run according to the existing corridors. There is already a social position coordinator in the mud village which is formed by the company and the village government so that it will facilitate and facilitate coordination in the implementation of CSR program implementation activities.

Gresik Petrochemicals, among others, the problem of disruption of coordination between companies and community actors / community leaders in the field often occurs so that the program implemented becomes delayed or even canceled. The implementation of checks from the company about the feasibility of the program carried out is often misunderstood by some people that the company does not want to help the area, this can become protracted when there is no agreement between the company and the recipient of the program which results in disruption of the program. There is a hidden conflict between the village head and LKMK, causing delays in coordination in implementing CSR programs.

\section{DISCUSSION OF RESULTS}

Implementation of Corporate Social Responsibility Program Gresik Petrochemicals can be fully implemented as mandated in the company's vision and mission. Implementation of Corporate Social Responsibility Program Gresik Petrochemicals based on the aspects contained in it has been effective and optimal and according to the expected target.

Based on the Standard Aspects and Policy Objectives, the implementation of Gresik Petrochemicals is carried out in accordance with SOPs and based on 6 pillars of sustainable development. If combined with 6 pillars of Corporate Social Responsibility according to Gresik Petrochemicals, the mindset is expected by the company to always strive to concentrate on creating sustainable products and sustainable construction, energy and climate (climate), resource conservation (resource conservation), and social commitment. All Corporate Social Responsibility programs use the partnership method.

Gresik Petrochemicals covers both quality and quantity. The composition of employees who are in the company is sufficient to fulfill the requirements, meaning that company employees have undergone education and training that is routinely carried out in this company as a refresher, the average employee has 10-20 years work experience so that he has experience in carrying out his duties The Department of Education and Training continues to provide training by working with other departments such as the Public Relations Bureau, HR Bureau, Partnership and Community Development Bureau, K3 Bureau and Personnel Bureau.

Based on the characteristics of the Implementing Organization, Gresik Petrochemicals Partnership and Community Development Bureau has carried out its duties well, all staff have the same implementation standards in accordance with applicable regulations in the company. According to Van Meter and Van Horn (1975), the variables that influence the implementation of public policy are bureaucratic structures. Even though the sources for 
implementing a policy are available or policy implementers know what should be done and have the desire to implement a policy, it is likely that the policy cannot be implemented or realized because of weaknesses in the bureaucratic structure.

Bureaucratic structure is a characteristic, norms and patterns of relationships that occur repeatedly in executive bodies that have both potential and real relationships with what they have in carrying out policies. Complex policies require the cooperation of many people. Elements that might influence an organization in policy implementation include the level of hierarchical supervision of sub unit decisions and processes in the implementing agency.

Based on the Communication Aspect that communication is carried out in the policies of Gresik Petrochemicals is carried out through two phases, namely internal communication carried out through delegation between implementers and all staff understanding the Program through policies that have been made in writing. External communication with the community, carried out by means of program socialization carried out by company officers to the community, as well as increasing cooperation with government agencies. According to Van Meter and Van Horn (1975) consistency of the information conveyed is needed in order to avoid confusion between the parties involved in its implementation. Likewise with the implementation of. Corporate Social Responsibility Program policies. Gresik Petrochemicals is highly demanded for consistency of information but if there is a change because it sees the condition of the community, information that circulates in the community automatically also changes

Petrochemical Gresik with policy makers in the Company, the findings of the research results show a positive attitude and support for the implementation of Gresik Petrochemicals, in terms of human resource capacity, the implementers of this policy have a willingness to accept the policies of Gresik Petrochemicals and readiness of carrying out tasks in accordance with the Letter of Assignments and procedures that have been available.

The Head of the Partnership Bureau can carry out the tasks well according to the existing SOPs in accordance with Ministerial Regulation Number PER-09 / MBU / 07/2015. In addition, all the Partnership and Community Development bureau staff have the ability and willingness to implement a policy, knowledge, understanding and deepening of policy. Such as providing an explanation of how the community submits an activity proposal or proposal to the target community

One of the factors that influence the effectiveness of policy implementation is the attitude of the implementor. If the implementor agrees with the contents of the policy then they will carry out happily but if their views differ from those of the policy maker then the implementation process will experience many problems. In addition, support from implementing officials is needed to achieve the program objectives. The manifestation of this leadership support includes placing policies as program priorities and providing sufficient funds to provide incentives for program implementers so that they support and work in total in implementing policies / programs.

Disposition is an aspect related to the attitude and support of the implementers of the program or policy. Attitudes and support are very important in the implementation process, because similarity of views on what is done together will facilitate the achievement of goals. If the implementers or implementors of the policy are divided in terms of attitudes and support, what will be achieved from a policy will not be achieved effectively and efficiently, because it will face many obstacles and obstacles from the implementing officers of the policy itself, where the implementation of programs or policies sometimes problematic if the executor involved in it cannot run the program or policy properly. If the implementer has a good disposition, then he will implement the program or policy well as cooled by policy makers, whereas if the implementer has a different attitude from the policy maker, then the implementation process of a program or policy will also not be effective and efficient

The attitude of the policy implementers with policy makers, the findings of the research shows a positive attitude and supports the implementation of the procedures for monitoring and controlling the mangrove area, in terms of the human resource capacity the implementers of this policy have the willingness to accept the policy and readiness to carry out tasks in accordance with the Letter of Assignment and available procedures. Based on 
the theory of Van Meter and Van Horn (1975) the appointment and selection of program implementing personnel must be the right people and have dedication to the tasks carried out. So that the implementation of a program can run effectively.

Based on the aspects of the Social, Economic and Political Environment, the K3 bureau understands that the environmental conditions in the location are quite safe and conducive. This means that all activities that take place in the area are running normally there are no significant turmoil / obstacles that occur between fellow elements of society

Based on the aspects of Performance Implementation, Corporate Social Responsibility Program Gresik Petrochemicals covers both physical and non-physical activities consisting of education and training such as scholarships, educational facilities and infrastructure assistance. In the field of health improvement carried out with free general treatment, mass circumcision, Fogging of dengue fever mosquitoes. Infrastructure infrastructure and facilities are carried out with village development. The economic sector provides investment assistance. The Field of Environmental Program is carried out with a greening program, cleaning program, emergency preparedness program.

\section{CONCLUSION}

Based on observations and interviews, it is known that the implementation of Corporate Social Responsibility programs as a whole, both standard instruments and policy objectives, resources, characteristics of implementing organizations, communication between organizations and implementing activities, dispositions or attitudes of implementers and social, economic / political environments can work well. This is also supported by the role of officers who carry out their duties properly and correctly according to the SOP

Supporting factors in the implementation of Corporate Social Responsibility programs are the formation of associations formed in the area of mud and the division of tasks for each coordinator that has been formed shows that the community is aware of the importance of communication between organizations. The standard policy for implementing CSR is a standard and policy targets show that the SOP for implementing CSR programs for StateOwned Enterprises is the same so all implementation of the program must refer to these rules, implementation of the program will be successful if the field implementers carry out standard operating procedures without prejudice local content in the community. Human resources are supporting factors that play a very important role in the implementation of this CSR program. The Public Relations Bureau and CSR Bureau must synergize in deciding and correcting the implementation of CSR programs. apart from that because it has sufficient education and training for officers in each department that has been programmed regularly. In communication between related organizations and implementation activities are well coordinated, so communication between superiors and subordinates can run well according to the SOP. On the social, economic / political aspects of the environment can work well. A polite culture in implementing the program is an added value for the success of the program.

Inhibiting factors in the implementation of CSR programs, is that there are still people who do not understand about the CSR program implemented. The delay in information on the implementation of CSR programs is due to lack of coordination between organizations. There are indications of covert competition that occurs between the Village Head and the Chair of the LKMK.

\section{RECOMMENDATIONS}

By considering the results of the research that has been concluded above and looking at several factors that support and hinder the implementation of the policy itself, the author formulates several recommendations and suggestions, among others, to the company Gresik Petrochemicals is recommended to: Continue to implement CSR programs in a sustainable manner by paying attention to the interests of the community. CSR activities / programs should not be just social activities but rather become sustainable activities and empower the community by carrying out training activities or fostered partners. 
Theoretically for future research needs to be explored more deeply about "Implementation of Corporate Social Responsibility Programs". The findings obtained in this study can be input and consideration for developing the following research so that the development of science, especially the science of public policy, grows in accordance with the development of time and age.

\section{REFERENCES}

1. Anderson, W., 1979.Intergovernmental Relations in Review, University of Minnesota Press, Minneapolis, MN.

2. Crowther, David 2008 Corporate Social Responsibility. Gulen Aras \& Ventus Publishing Aps.

3. Emzir. 2010. Metode Penelitian Kualitatif. Analisis Data. Rajawali Pers. PT. Grafindo Persada. Jakarta.

4. Finsterbusch, K. \& Partridge, W.L., 1990. The development anthropologicla approach. Oxford: Westview.

5. Hadi, Nor. 2011. Corporate Social Responsibility. Yogyakarta: Graha IImu.

6. Islamy, M. Irfan. 2000. Prinsip-prinsip Perumusan Kebijakan Negara. Jakarta. Sinar Grafika.

7. Parsons, Wayne. 2005. Public Policy Pengantar Teori dan Praktik Analisis Kebijakan. Jakarta: Prenada Media.

8. Subarsono, A.G. 2005. Analisis Kebijakan Publik Konsep, Teori dan Aplikasi. Yogyakarta: Pustaka Pelajar.

9. Carl Van Horn dan Donal Van Meter. 1975, Model-model dalam Kebijakan Implementasi, Yogyakarta.

10. Winarno, Budi. 2008. Kebijakan Publik: Teori dan Proses. Yogyakarta: Media Pressindo. 